\title{
Langerhans Cell Histiocytosis in the Thyroid and Draining Lymph Nodes: A Case Report
}

\author{
Dong Hae Chung ${ }^{1}$, Seung Yeon Ha ${ }^{1}$, Hyun Yee Cho' ${ }^{1}$, Na Rae Kim ${ }^{1}$, Jung Suk An ${ }^{1}$, Young-Don Lee ${ }^{2}$, Sanghui Park ${ }^{3}$ \\ Departments of Pathology ${ }^{1}$ and Surgery ${ }^{2}$, Gachon University School of Medicine, Incheon; Department of Pathology ${ }^{3}$, Ewha Womans University \\ School of Medicine, Seoul, Korea
}

A 53-year-old woman was presented with several 0.3-0.6 cm-sized nodules within the right lobe of the thyroid. Histologic sections of the thyroid demonstrated multiple papillary microcarcinomas in the background of lymphocytic thyroiditis, with a small focus of Langerhans cell histiocytosis (LCH). Small LCH nodules were also found in the draining cervical lymph nodes. Although the association of LCH with papillary thyroid carcinoma in the thyroid has been reported, their co-existence with LCH in the draining lymph nodes is very rare. (Endocrinol Metab 27:138-141, 2012)

Key Words: Langerhans cell histiocytosis, Thyroid papillary carcinoma, Thyroid gland

\section{INTRODUCTION}

Langerhans cell histiocytosis (LCH) is a rare disorder characterized by proliferation of abnormal clusters of differentiation 1a-positive (CD1a) dendritic cells [1]. It may cause local or systemic effect $[1,2]$. LCH may be associated with Hodgkin's disease, non-Hodgkin's lymphomas, carcinomas and other solid tumors [3,4]. A limited number of thyroid LCH with co-existing papillary carcinoma has been reported in the literature. Involvement of the thyroid gland can be focal or diffuse, and results in organ involvement, occasionally accompanied by nodular goiter, lymphocytic thyroiditis, or papillary carcinoma [5,6]. Moreover, LCH occurring in lymph nodes draining thyroid papillary carcinoma is extremely rare. We report a very rare case of thyroid LCH with papillary carcinoma and co-existing LCH of draining lymph nodes.

\section{CASE REPORT}

A 53-year-old woman presented with a progressively enlarging thyroid over 5 years. Laboratory studies including thyroid function tests, chemistry profile, complete blood cell count with differential, platelet count, red blood cell distribution width, and prothrombin and partial thromboplastin times were all within the normal limits. Thyroid function studies disclosed free T4 and T3 levels were within the normal limits.

Ultrasonography revealed three calcified masses measuring 0.6, 0.4 , and $0.3 \mathrm{~cm}$. Fine needle aspiration was performed several times but failed due to inadequate specimen.

The patient underwent right thyroid lobectomy with right lymph node dissection. Pathologic examination of the right lobe revealed multiple calcified nodules measuring up to $0.6 \mathrm{~cm}$ in the greatest dimension.

Microscopic examination of the nodules revealed papillary microcarcinomas (Fig. 1). The remainder of the thyroid tissue showed lymphocytic thyroiditis and a separate, incidental, $0.5 \mathrm{~cm}$-sized nodule (Fig. 2A). Microscopic examination of this nodule revealed poorly circumscribed proliferation of large cells effacing the follicular architecture of the thyroid. The cells comprising the nodules were arranged in sheets and small cluster, and exhibited abundant eosinophilic cytoplasm and bean-shaped, folded nuclei admixed with eosinophils (Fig. 3). Immunohistochemical stain for S100 was strongly positive in the large cells with folded nuclei, while pancytokeratin was negative (Fig. 2B, C). Although immunohistochemical stain for CD1a and electron microscopy were not performed,
Received: 9 June 2011, Accepted: 22 August 2011

Corresponding author: Sanghui Park

Department of Pathology, Ewha Womans University Mokdong Hospital, Ewha

Womans University School of Medicine, 1071 Anyangcheon-ro, Yangcheon-gu, Seoul 158-710, Korea

Tel: +82-2-2650-5731, Fax: +82-2-2650-2879, E-mail: spark0430@ewha.ac.kr
Copyright $\odot 2012$ Korean Endocrine Society

This is an Open Access article distributed under the terms of the Creative Commons Attribution Non-Commercial License (http://creativecommons.org/licenses/by-nc/3.0/) which permits unrestricted non-commercial use, distribution, and reproduction in any medium, provided the original work is properly cited. 


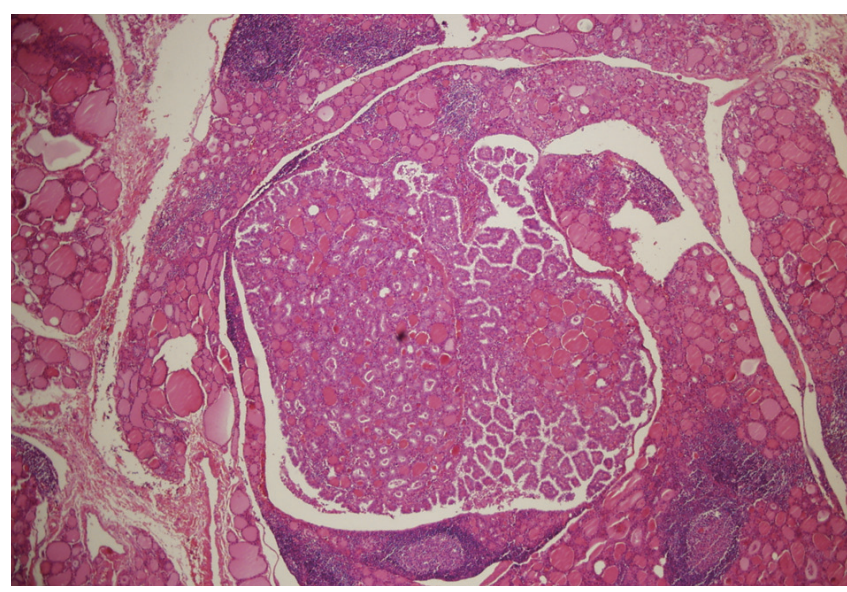

Fig. 1. Papillary microcarcinoma of the thyroid in the background of lymphocytic thyroiditis (H\&E stain, $\times 40)$.
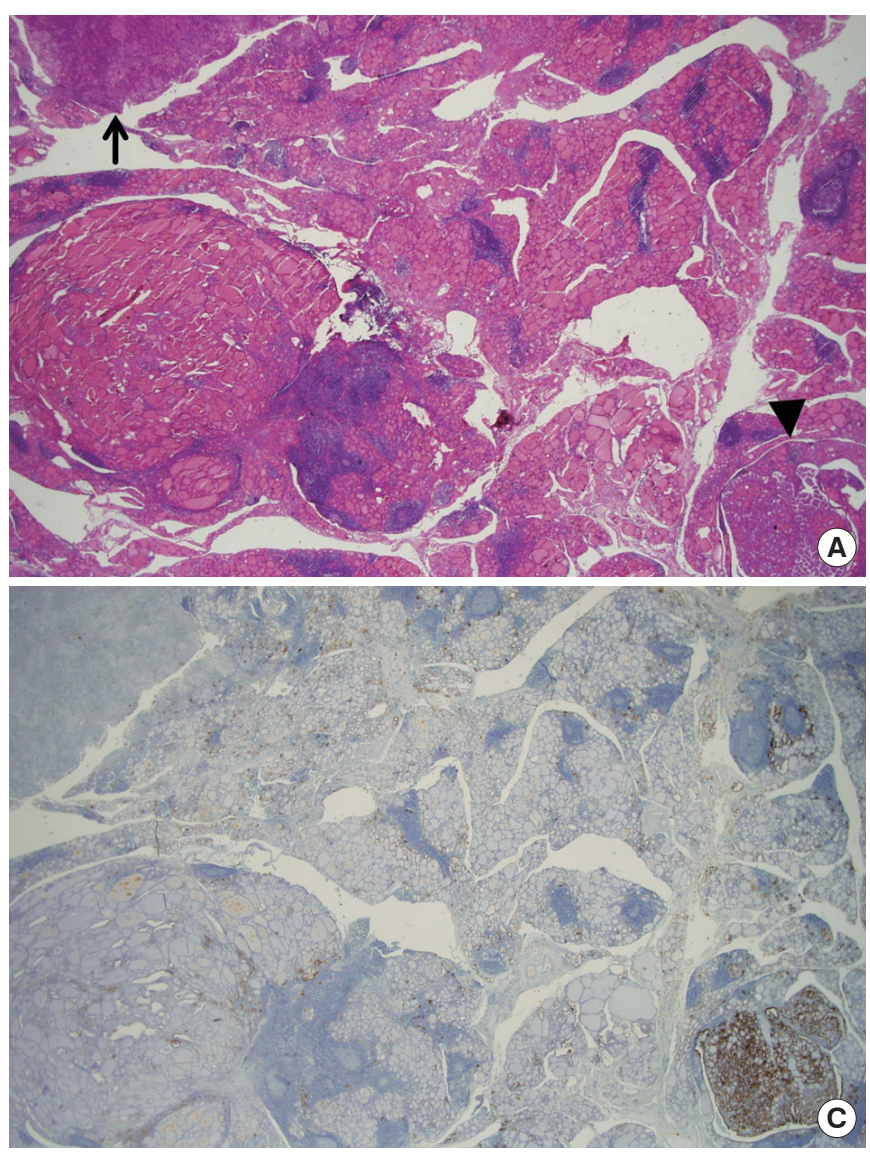

the diagnosis of LCH of the thyroid gland was made based on microscopical and immunohistochemical results. Examination of the right paratracheal lymph nodes revealed incidental, small nodules measuring up to $0.2 \mathrm{~cm}$ in the greatest dimension, and the nodules showed clusters of cells with abundant eosinophilic cytoplasm and bean-shaped, folded nuclei admixed with eosinophils (Fig. 4A). The

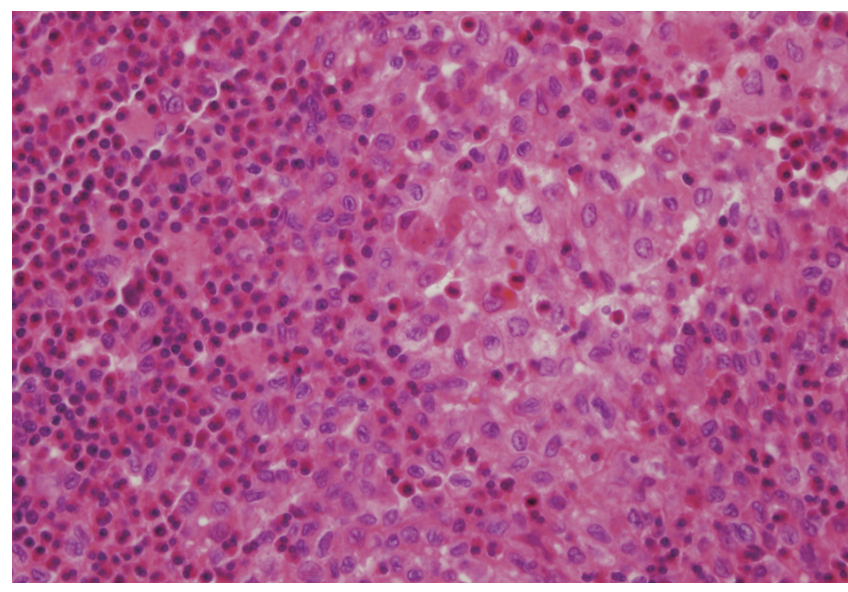

Fig. 3. Sheets of Langerhans cells with eosinophils (H\&E stain, $\times 400)$.

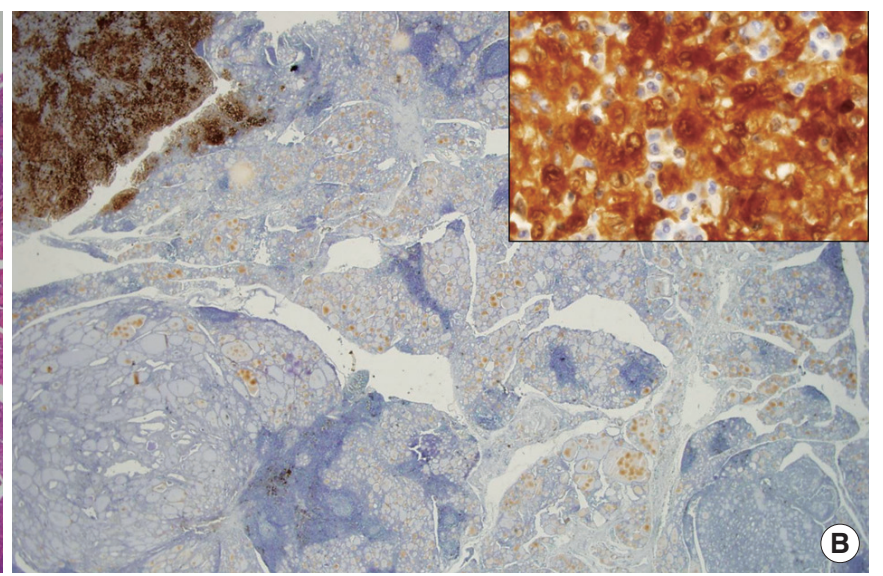

Fig. 2. A. The remainder of the thyroid tissue showed lymphocytic thyroiditis and a separate, incidental, $0.5 \mathrm{~cm}$-sized nodule (left top-arrow) and papillary microcarcinoma is also identified (right bottom-arrowhead) (H\&E stain, scanning view, $\times 12.5)$. B. Immunohistochemical stain for $\$ 100$ was strongly positive in the large cells with folded nuclei ( $\times 12.5$; inset, $\times 400)$, C. while pancytokeratin was negative $(\times 12.5)$.

diagnosis of LCH in draining lymph nodes was made. Immunohistochemical stain for S100 was strongly positive in the large cells with folded nuclei (Fig. 4B).

Evidence of LCH multi-focality was not confirmed because follow-up studies, such as bone marrow aspiration and biopsy, bone scan, and computed tomography of the neck, chest, abdomen, and 

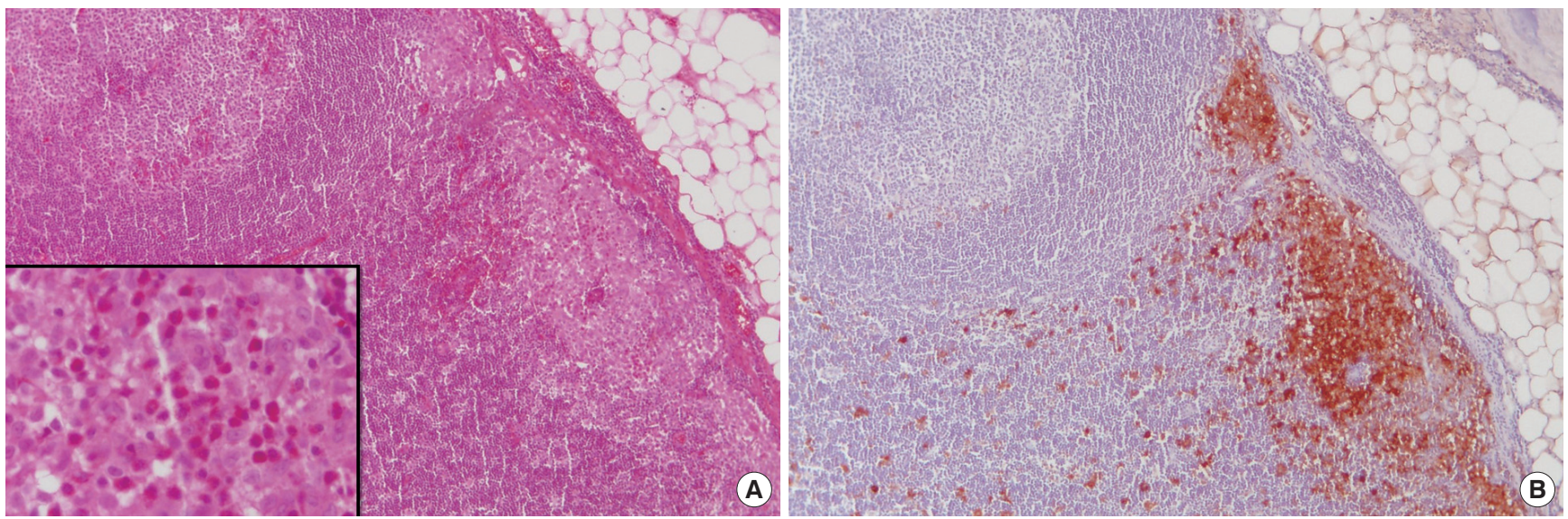

Fig. 4. A. Low-power photograph of a lymph node showing aggregates of pale staining cells (H\&E stain, $\times 100$; inset, $\times 400)$. B. Sections stained with antibody to S100 protein. There is intense nuclear and cytoplasmic staining of Langerhans cells.

Table 1. Clinicopathologic features of previously reported cases showing thyroid papillary carcinoma associated with LCH in lymph nodes

\begin{tabular}{|c|c|c|c|c|c|c|c|c|c|c|}
\hline Case & Year & Age/Sex & Side & $\begin{array}{l}\text { Tumor } \\
\text { size }\end{array}$ & Gross & $\begin{array}{l}\text { Tumor } \\
\text { type }\end{array}$ & $\begin{array}{l}\text { Lymphocytic } \\
\text { thyroiditis }\end{array}$ & $\begin{array}{l}\text { LN } \\
\text { meta }\end{array}$ & $\begin{array}{l}\text { LCH in } \\
\text { thyroid }\end{array}$ & LCH in LN \\
\hline $1(14)$ & 1990 & $55 / M$ & $\mathrm{Lt}$ & $5 \mathrm{~cm}$ & $\begin{array}{l}\text { Ill-defined, firm, } \\
\text { white }\end{array}$ & PC & None & Yes & None & Yes (draining LN) \\
\hline $2(13)$ & 1996 & $51 / \mathrm{M}$ & Rt & $0.3 \mathrm{~cm}$ & Firm, dark brown & PC & None & Yes & None & Yes (draining LN) \\
\hline $3(12)$ & 1998 & $22 / F$ & $\mathrm{Lt}$ & ND & ND & PC & ND & None & None & Yes* \\
\hline Present case & 2010 & $53 / F$ & Rt & Up to $0.6 \mathrm{~cm}$ & Multiple, calcified & $\mathrm{PC}$ & Yes & Yes & Yes & Yes (draining LN) \\
\hline
\end{tabular}

* This patient re-presented with a painful LN measuring $1.2 \mathrm{~cm}$ in the left posterior triangle (distant LN) 2 months later.

F, female; LCH, Langerhans cell histiocytosis; LN, lymph node; Lt, left; M, male; ND, not described; PC, papillary carcinoma; Rt, right.

pelvis were not performed in this patient.

\section{Materials and methods}

Hematoxylin-eosin-stained sections were examined. Immunohistochemical studies were conducted on formalin-fixed, paraffinembedded, $4 \mu \mathrm{m}$-thick tissue sections. The primary antibodies used were murine monoclonal anti-pancytokeratin (prediluted; AE1/AE3, Dako, Glostrup, Denmark), and S-100 (prediluted; Dako). Tissue sections were deparaffinized three times in xylene for a total of 15 minutes and subsequently rehydrated. Immunostaining was performed using a Bond-max autoimmunostainer (Leica Biosystem, Melbourne, Australia) with ER1 or ER2 retrieval buffers and a Bond Polymer refine detection system DS9800 (Vision Biosystems, Melbourne, Australia).

\section{DISCUSSION}

Even though limited numbers of thyroid LCH with co-existing papillary carcinoma has been reported in the literature [6-10], asso- ciation with papillary thyroid carcinoma is more often described [11]. However, LCH is very rarely found in lymph nodes draining papillary carcinoma of the thyroid. To the best of our knowledge, only three cases had been reported in the English literature to date [12-14], and this is the first case to be found in Korea [15]. Clinocopathologic features of previously reported cases were described in Table 1. Although one Korean case with multifocal LCH in the thyroid gland has been reported, that case did not showed papillary carcinoma of the thyroid. Moreover, our case is unique because LCH is identified in the thyroid gland and the draining lymph nodes simultaneously. In three previously reported cases, thyroid LCH was not co-existing [12-14].

The etiology of LCH remains unknown. Ambivalence persists as to whether this disorder is primarily neoplastic, immunodysregulatory, or reactive with neoplastic and immunodysregulatory characteristics $[16,17]$. Many reported cases of LCH of the thyroid have been associated with lymphocytic thyroiditis $[3,18]$. Coexistence of thyroid LCH and LCH in draining lymph nodes in our case appears to be an incidental finding, even though there remains a possibility 
that the LCH arose in response to carcinoma and lymphocytic thyroiditis. However, thyroid carcinoma developed years after $\mathrm{LCH}$ diagnosis has been made [3]. Thus, thyroid LCH should raise the possibility of other associated disorders.

It has been suggested that LCH cells may alter their migratory properties through the expression of various cytokine receptors and by releasing inflammatory chemokines, causing not only retention of lesional Langerhans cells but also recruitment of eosinophils and T lymphocytes, as well as resultant development of lymphocytic thyroiditis. Lindley et al. [12] reported a very interesting case, which showed that one patient with history of left thyroid lobectomy for papillary carcinoma re-presented with a painful lymph node in the left posterior triangle showing $\mathrm{LCH}$ without metastasis two month later. This case suggests that Langerhans cell proliferation may be a reactive phenomenon, probably through the expression of cytokine or chemokine receptors.

In conclusion, LCH associated with papillary thyroid carcinoma and lymph nodes is uncommon. However, it should be borne in mind that LCH in the thyroid gland or lymph nodes can be associated with papillary carcinoma, because LCH may present a diagnostic challenge to the unsuspected pathologist, especially when dealing with aspirates from cervical lymph nodes for metastatic work-up.

\section{요 약}

53세 여자 환자가 갑상선 우엽에서 0.3-0.6 cm 크기의 다양한 종 괴가 발견되어 내원하였다. 조직소견상 림프구성 갑상선염 배경 하 에, 갑상선미세유두암 여러 개가 관찰되었으며, 작은 랑게르한스 세 포조직구증식증이 주위에서 관찰되었다. 배액경부림프절에도 랑게 르한스 세포조직구증식증이 관찰되었다. 갑상선에서 갑상선미세유 두암과 랑게르한스 세포조직구증식증이 함께 동반하는 것은 드물 지만 가끔 보고되고 있다. 하지만, 배액경부림프절에서도 랑게르한 스 세포조직구증식증이 발견되는 것은 매우 드물다.

\section{REFERENCES}

1. Favara BE, Feller AC, Pauli M, Jaffe ES, Weiss LM, Arico M, Bucsky P, Egeler RM, Elinder G, Gadner H, Gresik M, Henter JI, Imashuku S, Janka-Schaub G, Jaffe R, Ladisch S, Nezelof C, Pritchard J: Contemporary classification of histiocytic disorders. The WHO Committee on histiocytic/reticulum cell proliferations. Reclassification Working Group of the Histiocyte Society. Med Pediatr Oncol 29:157-166, 1997
2. Fleming MD, Pinkus JL, Fournier MV, Alexander SW, Tam C, Loda M, Sallan SE, Nichols KE, Carpentieri DF, Pinkus GS, Rollins BJ: Coincident expression of the chemokine receptors CCR6 and CCR7 by pathologic Langerhans cells in Langerhans cell histiocytosis. Blood 101:2473-2475, 2003

3. Egeler RM, Neglia JP, Puccetti DM, Brennan CA, Nesbit ME: Association of Langerhans cell histiocytosis with malignant neoplasms. Cancer 71:865-873, 1993

4. Howarth DM, Gilchrist GS, Mullan BP, Wiseman GA, Edmonson JH, Schomberg PJ: Langerhans cell histiocytosis: diagnosis, natural history, management, and outcome. Cancer 85:2278-2290, 1999

5. Coode PE, Shaikh MU: Histiocytosis $\mathrm{X}$ of the thyroid masquerading as thyroid carcinoma. Hum Pathol 19:239-241, 1988

6. Saiz E, Bakotic BW: Isolated Langerhans cell histiocytosis of the thyroid: a report of two cases with nuclear imaging-pathologic correlation. Ann Diagn Pathol 4:23-28, 2000

7. Burnett A, Carney D, Mukhopadhyay S, Scalzetti EM, Leino D, Souid AK: Thyroid involvement with Langerhans cell histiocytosis in a 3-yearold male. Pediatr Blood Cancer 50:726-727, 2008

8. Foulet-Rogé A, Josselin N, Guyetant S, Gardet JJ, Besancon A, SaintAndré JP, Fabiani B: Incidental langerhans cell histiocytosis of thyroid: case report and review of the literature. Endocr Pathol 13:227-233, 2002

9. Goldstein N, Layfield LJ: Thyromegaly secondary to simultaneous papillary carcinoma and histiocytosis $\mathrm{X}$. Report of a case and review of the literature. Acta Cytol 35:422-426, 1991

10. Thompson LD, Wenig BM, Adair CF, Smith BC, Heffess CS: Langerhans cell histiocytosis of the thyroid: a series of seven cases and a review of the literature. Mod Pathol 9:145-149, 1996

11. Vergez S, Rouquette I, Ancey M, Serrano E, Caron P: Langerhans cell histiocytosis of the thyroid is a rare entity, but an association with a papillary thyroid carcinoma is often described. Endocr Pathol 21:274-276, 2010

12. Lindley R, Hoile R, Schofield J, Ashton-Key M: Langerhans cell histiocytosis associated with papillary carcinoma of the thyroid. Histopathology 32:180, 1998

13. Safali M, McCutcheon JM, Wright DH: Langerhans cell histiocytosis of lymph nodes: draining a papillary carcinoma of the thyroid. Histopathology 30:599-603, 1997

14. Schofield JB, Alsanjari NA, Davis J, MacLennan KA: Eosinophilic granuloma of lymph nodes associated with metastatic papillary carcinoma of the thyroid. Histopathology 20:181-183, 1992

15. Lee KW, Chung CK, Hwang SC, Yim HH, Park SY, Lee SK, Chung YS, Kim HM, Kim YJ, Hong EK, Chae BN: A case with multifocal Langerhans cell granulomatosis involving the thyroid gland. J Korean Soc Endocrinol 13:466-472, 1998

16. Hoover KB, Rosenthal DI, Mankin H: Langerhans cell histiocytosis. Skeletal Radiol 36:95-104, 2007

17. Stockschlaeder M, Sucker C: Adult Langerhans cell histiocytosis. Eur J Haematol 76:363-368, 2006

18. Lieberman PH, Jones CR, Steinman RM, Erlandson RA, Smith J, Gee T, Huvos A, Garin-Chesa P, Filippa DA, Urmacher C, Gangi MD, Sperber M: Langerhans cell (eosinophilic) granulomatosis. A clinicopathologic study encompassing 50 years. Am J Surg Pathol 20:519-552, 1996 